\title{
SCIDoc

\section{Ophthalmic Zoster with Keratitis: A Rare Skin Disease in Children}

Chaouche $\mathrm{M}^{*}$, Dah Cherif A, Barbach Y, Elloudi S, Baybay H, Mernissi FZ

Dermatology Department, University Hospital Hassan II, Fez, Morocco.

\section{Abstract}

Herpes zoster and varicella are the two main clinical presentations of the varicella zoster virus infection. Varicella is the manifestation of primary infection. It is a systemic infection, frequent in childhood. Herpes zoster is a reactivation of the virus. It often occurs in immunocompromised situations. Several localizations can be observed in herpes zoster.

Herpes zoster ophthalmicus, although not uncommon in adults, is rarely found in children. Here in we present a case of pediatric herpes zoster ophthalmicus in an immunocompetent boy of 6 years old, with zoster keratitis.

Keywords: Ophthalmic Zoster; Varicella; Immunocompetent; Child.

Abbreviations: VZV: Varicella - Zoster Virus; HZO: Herpes Zoster Ophthalmicus.

\section{Introduction}

Herpes zosteris a reactivation of the virus varicella zoster and is usually a disease of the elderly. Childhood herpes zoster is believed to be rare, and particularly the ophthalmic form, defined as herpes zoster of the ophthalmic branch of the fifth cranial nerve [1]. This can be responsible for serious eye complications requiring adequate and early management [2]. We report a new case in an immunocompetent boy of 6 years old, with zoster keratitis.

\section{Case Report}

A 6-year-old child, with no pathological antecedents, presented with a left vesicular-crusted frontal rash [Figure 1] evolving in a context of fever and general state preservation. The evolution was marked by a rapid extension of lesions with conjunctival hyperemia and tearing, without pruritus. The ophthalmic examination with the slit lamp and the fundus eye was in favor of zoster keratitis, and then put on emergency aciclovir. The evolution was marked by clinical improvement with regression of oedema and pain. A minimal biological analysis was performed including a normal blood count, blood sugar and HIV serology. The current retreat is 6 months without any recurrence or post-herpetic pain.

\section{Discussion}

Herpes Zoster (HZ), also referred to as shingles, is caused by reactivation of the varicella-zoster virus $(V Z V)$ in people who have had chickenpox (varicella), the primary infection caused by VZV, typically resulting in a painful, unilateral, dermatomal vesicular rash. About $20 \%$ of $\mathrm{HZ}$ involve the first division (ophthalmic) of cranial nerve $\mathrm{V}$ (trigeminal) resulting in $\mathrm{HZO}$ [2].

Historically, childhood herpes zoster was thought to be an indicator for an underlying malignancy, especially acute lymphatic leukemia, whereas recent studies have shown no increase in the incidence of malignancy in children with herpes zoster. Approximately $3 \%$ of the pediatric zoster cases occur in children with malignancies. Rising incidence of herpes zoster in otherwise healthy children may be due to acquiring primary varicella infection in utero, or in infancy, where in the immunity is not fully developed. Vaccination with live attenuated virus may also contribute [3, 4]. $\mathrm{HZO}$ usually begins with pain and an erythematous maculopapular, then vesicular rash in the dermatomal distribution of the trigeminal nerve. The ophthalmic division of the trigeminal nerve can be divided into the frontal, lacrimal and nasociliary nerves.

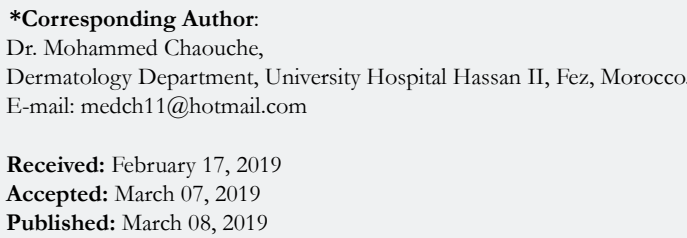

Copyright: Chaouche $\mathbf{M}^{\top}$ 2019. This is an open-access article distributed under the terms of the Creative Commons Attribution License, which permits unrestricted use, distribution and reproduction in any medium, provided the original author and source are credited. 
Figures 1. Frontal Vesicular Crustal Eruption in 6 Years Old Child.

Involvement of the eye is most common when accompanied by vesicles on the tip or side of the nose, indicating that the nasociliary branch of V-1 is affected. This isknown as a positive Hutchinson's sign. Ophthalmic involvement presents clinically with a painful red eye, most commonly caused by corneal keratitis and/ or uveitis, subconjunctival haemorrhage can also be an initial presentation of HZO in children [5]. Occasionally, other rashes mimiczoster, including herpes simplex skin infection, contact dermatitis and staphylococcal impetigo. Conjunctivitis or bacterial uveitis may have similar presentation to that of $\mathrm{HZO}$, particularly when the skin rash isless distinct. It is important to distinguish $\mathrm{HZO}$ from these other conditions, to ensure an appropriate treatment and prevent complications. Acyclovir is the first choice treatment for children and the suggested dose is $10 \mathrm{mg} / \mathrm{kg}$ every 8 hours for 7 days. Starting with in 72 hours of initial symptoms significantly reduces adverse outcome. Topical steroids are recommended for treatment of conjunctival, corneal and uveal inflammation. Post herpetic neuralgia can be reduced by treating the patient with antiviral within the first 24 hours of symptom on set [6].

The particularity of our observation is the occurrence of herpes zoster in an immunocompetent child, without notion of anterior chickenpox and the ophthalmic localization with zoster keratitis which remains a rare form in the child.

\section{Conclusion}

Although herpes zoster ophtalmicus is uncommon in children, its occurrence in immunocompetent patients could lead to sightthreatening complications. Early presentation and prompt treatment will no doubt minimize morbidity.

\section{References}

[1]. Komitova RT, Boykinova OB, Stoyanova NS. The Skin and the Eye-Herpes Zoster Ophthalmicus in a Healthy 18-month-old Toddler. Folia Med (Plovdiv). 2018 Mar 1;60(1):170-174. doi: 10.1515/folmed-2017-0064. PubMed PMID: 29668453.

[2]. Olubanjo OO. Herpes Zoster In A Healthy Nigerian Child: A Case Report. Internet J Pediatr Neonatol. 2007;9(1).

[3]. Katakam BK, Kiran G, Kumar U. A prospective study of herpes zoster in children. Indian J Dermatol. 2016 Sep-Oct;61(5):534-9. doi: 10.4103/0019-5154.190121. PubMed PMID: 27688444.

[4]. Prabhu S, Sripathi H, Gupta S, Prabhu M. Childhood herpes zoster: A clustering of ten cases. Indian J Dermatol. 2009;54(1):62-4. doi: 10.4103/00195154.48991. PubMed PMID: 20049274.

[5]. Soeteman M, Willems RP, Busari JO. Herpes zoster ophthalmicus in an otherwise healthy 2-year-old child. BMJ Case Rep. 2012 Oct 30;2012. doi: 10.1136/bcr-2012-007015. PubMed PMID: 23112258.

[6]. Opstelten W, Eekhof J, Neven AK, Verheij T. Treatment of herpes zoster. Can Fam Physician. 2008 Mar;54(3):373-7. PubMed PMID: 18337531. 